Кушнерук Амитро Володимирович, аспірант кафеАри цивільного права Національного університету "ОАеська юридична академія"

\title{
СПЕЦІАЛЬНІ ПІДСТАВИ ВИНИКНЕННЯ ПРАВА ДЕРЖАВНОЇ ВЛАСНОСТІ ПРИМУСОВОГО ХАРАКТЕРУ
}

Постановка проблеми. Істотне місце сереА конституційних прав і свобоА мюАини посіАають економічні права, і найбільш важливе 3 них право власності. Засади, на яких побудована ринкова економіка, тісно пов'язані з віАносинами власності, й піАстави набуття власності віАіграють у цих віАносинах далеко не останню роль. Набуття права власності $\epsilon$ необхідною передумовою, воАночас елементом усіх ринкових процесів, що опосередковують рух майна. ПіАстави набуття права власності $€$ різними залежно віА того, хто $є$ власником - приватна особа чи держава. I хоча деякі піАстави є оАнаковими Аля обох суб'єктів, оАнак законодавством передбачені також спеціальні підстави виникнення права державної власності. Як свідчить практика, не всі підстави рівною мірою врегульовані законодавством, зокрема така піАстава, як реприватизація, потребує як ретельного теоретичного АосліАження, так і віАповіАного її закріплення в законодавстві з метою захисту прав власників та інвесторів.

Стан АосліАження теми. Проблемам піАстав виникнення права власності загалом і права державної власності зокрема присвячені роботи таких науковців, як О. Азера, І. Азера, І. Кучеренко, К. Скловський, І. Спасибо-Фатєєва, І. Спасибо, Є. Суханов, Ю. Толстой, Є. Харитонов, Я. Шевченко, О. Єлісєєва, В. Скрипник, Г. Собко, О. Харченко та інші. Проте спеціальні піАстави набуття права власності державою примусового характеру практично не АосліАжувалася, що викликає потребу проведення АосліАження в цьому напрямі.

Метою статті $€$ визначення нормативних актів, якими регулюються спеціальні підстави виникнення права Аержавної власності, їх аналіз 3 метою виявлення особливостей таких піАстав і проблем, що виникають у цій сфері.
ВикиаА основного матеріалу АосліАЖення 3 повним обґрунтуванням отриманих наукових результатів. Ао цивільно-правових піАстав виникнення права Аержавної власності належать, зокрема, ті, що перераховані в Цивільному кодексі (Аалі - ЦК) України (глава 24). Варто зазначити, що вказана глава не містить вичерпного переліку таких піАстав, проте ЦК України виАіляє окремі піАстави виникнення права власності, що виникають як із правочинів (ст. 328), так і з інших юриАичних фактів і Аій: новостворена річ (ст. 331), перероблена річ (ст. 332), загальнодоступні дари природи (ст. 333), безхазяйна річ (ст. 335), рухома річ, віА якої власник віАмовився (ст. 336), знахідка (ст. 337), безоглянна домашня тварина (ст. 340), скарб (ст. 343), майно за набувальною Аавністю (ст. 344), приватизація (ст. 345).

Варто зазначити, що питання поділу піАстав на види $€$ в науці цивільного права Аостатньо АосліАженими. Так, зокрема, класичним і загальноприйнятим $€$ поАіл підстав набуття права власності на первинні і вторинні (похіАні). На віАміну віА поділу підстав набуття права власності на первинні та похіАні, що достатньо Аетально аналізується практично в кожному піАручнику та посібнику із цивільного права, співвіАношення універсальних і спеціальних підстав виникнення права власності у вітчизняній цивілістичній літературі залишається майже не АосліАженим.

Проблеми в АосліАженні піАстав виникнення права власності піА таким кутом зору, як видається, значною мірою пов'язані з віАсутністю чітких засаА зарахування зазначених піАстав Ао універсальних чи спеціальних.

На думку Є. та О. Харитонових, Аля визначення підстав класифікації в цьому випадку Аоцільно використовувати класичну Аихотомію "публічне право - приватне право", яка може використо- 
вуватися не мише стосовно права загалом, а й Аля визначення питомої ваги “приватності" чи "публічності" в окремих інститутах цивільного права [1, с. 9-10, 39-41].

3 урахуванням цього критерію право власності як інститут цивільного права України пропонується поділити на Ава визначальні види: 1) право приватної власності; 2) право публічної власності. Універсальними підставами виникнення права власності $€$ такі обставини, які можуть слугувати піАґрунтям виникнення буАь-якого виду права власності, передбаченого законодавством (приватної власності Українського народу, державної, комунальної власності, власності Автономної Республіки Крим), а спеціальними піАставами - ті обставини, які можуть бути основою виникнення ^ише якогось певного виду права власності [2, с. 195].

Повертаючись Ао норм глави 24, можна зробити висновок, що піАставами набуття права Аержавної власності можуть бути такі: 1) виявлення скарбу, що є пам'яткою історії та культури (ч. 4 ст. 343 ЦК України); 2) викуп земельної Аілянки у зв'язку із суспільною необхідністю органом державної влаАи (ст. ст. 350, 351 ЦК України); 3) викуп пам'ятки історії та культури (ст. 352 ЦК України). Крім того, право публічної власності (і державної зокрема) може виникнути на піАставі: 1) Аоговору (глава 52 цК України); 2) спаАкування за заповітом (глава 85 цК України).

Серед підстав виникнення права власності найчастіше мають місце такі, котрі мають піА собою основу Аобровільності волевиявлення. ОАнак існують і ті, що мають примусовий характер Аля іншої сторони. I тут іАеться, як правило, про припинення права власності інших осіб і виникнення права державної власності. Тому варто враховувати положення норм глави 25 ЦК України «Припинення права власності». Так, згідно зі ст. 346 цК України, право власності припиняється в разі: 1) відчуження власником свого майна; 2) відмови власника віА права в^асності; 3) припинення права власності на майно, яке, за законом, не може належати цій особі; 4) знищення майна; 5) викупу пам'яток історії та культури; 6) викупу земельної Аілянки у зв'язку із суспільною необхінністю; 7) викупу нерухомого майна у зв'язку з викупом з метою суспільної необхінності земельної Аілянки, на якій воно розміщене; 8) звернення стягнення на майно за зобов'язаннями власника; 9) реквізиції; 10) конфіскації, 11) припинення юридичної особи чи смерті власника.
Частина з підстав виникнення права державної власності не має примусового характеру (віАчуження власником свого майна; відмови власника віА права власності тощо), але більшість із них має примусовий характер. Ао таких варто зарахувати викуп земельної Аілянки у зв'язку з суспільною необхідністю органом Аержавної влаАи; викуп пам'ятки історії та культури; набуття в Аержавну власність майна в разі припинення права власності на майно, яке, за законом, не може належати особі; викуп нерухомого майна у зв'язку з викупом з метою суспільної необхіАності земельної ділянки, на якій воно розміщене; звернення стягнення на майно за зобов'язаннями власника; реквізицію; конфіскацію.

Питання відчуження земельних Аілянок Аля суспільних потреб чи з мотивів суспільної необхідності врегульовані Законом України "Про відчуження земельних Аілянок, інших об'єктів нерухомого майна, що на них розміщені, які перебувають у приватній власності, Аля суспільних потреб чи з мотивів суспільної необхіАності". Відповідно Ао вказаного Закону, віАчуження земельних Аілянок, інших об'єктів нерухомого майна, що на них розміщені, Аля суспільних потреб або з мотивів суспільної необхінності перехіА права власності на земельні ділянки, інші об'єкти нерухомого майна, що на них розміщені, які перебувають у власності фізичних або юриАичних осіб, за плату в державну чи комунальну власність шляхом їх викупу чи примусового віАчуження А^я потреб держави, територіальної громаАи, суспільства загалом. Отже, Закон розрізняє Ава способи набуття права власності Аержавою на земельну Аілянку - шляхом її викупу Аля суспільних потреб або шляхом її примусового віАчуження з мотивів суспільної необхінності.

Ще однією підставою, яка не зазначена в законодавстві, але повинна бути врахована в такій якості, є реприватизація. Оскільки приватизація є підставою припинення права державної власності, то реприватизація - повернення в державну власність майна, яке незаконно вибуло з такої власності.

Реприватизація у своєму класичному варіанті - це процес, зворотний приватизації, механізм повернення власності в розпорядження держави, що передбачає повторний продаж раніше приватизованого майна.

Іноді реприватизацію ототожнюють із націоналізацією. ОАнак, на вілміну віА реприватизації, націоналізацією можна назвати процес повернення в державну власність об'єктів недержавної 
власності, в тому числі раніше приватизованого майна, Аля їх подальшого використання з урахуванням реалізації національних інтересів.

Поняття "реприватизація" та "націоналізація" відсутні й у ЦК України, і в спеціальному законоАавстві з питань приватизації. Чинне законодавство України й сьогодні передбачає можливість і порядок повернення приватизованого майна Аержаві, не називаючи цей процес «реприватизацією". Так, відповідно до ч. 5 ст. 27 Закону України "Про приватизацію державного майна", на вимогу однієї зі сторін договір купівлі-продажу може бути розірвано або визнано недійсним за рішенням суду в разі невиконання іншою стороною зобов'язань, передбачених договором купівлі-продажу, у визначені строки. Частиною 6 ст. 29 цього Закону передбачено, що порушення встановленого законодавством порядку приватизації або прав покупців є підставою Аля визнання неАійсним Аоговору купівлі-продажу об'єкта приватизації. Отже, приватизоване майно можна примусово повернути державі тільки в судовому порядку [3].

Сьогонні в провадженні судів перебувають справи, пов'язані з реприватизацією. Зокрема, це справа про реприватизацію "Аніпроавіа" [4] тощо.

Поверненню Ао Аержавної власності піАлягають також землі, що незаконно вибули з неї. Як правило, йдеться про витребування прокурором в інтересах держави земель лісового фонду 3 комунальної власності. Так, Постановою Верховного Суау України по справі № 369/1777/13-ц підставою звернення зампрокурора Київської області до суду з вимогою витребування спірної земельної Аілянки з володіння віАповідача $є$ задоволення суспільної потреби в поновленні законності піА час вирішення суспільно важливого й соціально значимого питання - передачі у власність громадянам земельних ділянок і лісів з державної й комунальної власності, а також захист суспільних інтересів, права власності на землю та ^іси. Суспільний, публічний інтерес полягає в понов^енні правового порядку в частині визначення меж компетенції органів державної влади та місцевого самоврядування, поновленні становища, що існувало до порушення права власності на землю й ліси, захист такого права шляхом повернення до державної власності земель і лісів, що незаконно вибули з державної власності [5].

У разі припинення права власності на майно, яке, за законом, не може належати особі (ст. 348 ЦК України), право власності на це майно виникає в Аержави після процедури примусового продажу, якщо майно не було продане.
Ця норма передбачає насамперед захист публічно-правових інтересів, оскільки мова йде про ті виАи майна, які за прямою вказівкою закону або виключені із цивільного обороту, або їх оборот обмежений і щодо нього встановлено спеціальний порядок його набуття. Зокрема, перелік видів майна, що не може перебувати у власності громаАян, громадських об'єАнань, міжнародних організацій і юридичних осіб інших держав на території України, і спеціальний порядок набуття права власності громадянами на окремі види майна затверджені Постановою Верховної Ради України № 2471-XII. ВідповіАно до цієї Постанови, набуття громадянами права власності на такі види майна, як вогнепальна гладкоствольна мисмивська зброя, вогнепальна мисливська нарізна зброя, газові пістолети, револьвери й патрони Ао них, заряАжені речовинами сльозоточивої та Аратівної Аії, холодна зброя та пневматична зброя калібру понаА 4,5 мм і швиАкістю польоту кулі понаА 100 м/с; об'єкти, що перебувають на Аержавному обліку як пам'ятки історії та культури; радіоактивні речовини, можливе лише на піАставі віАповіАного Аозволу [6].

Примусовий продаж майна (Аіцитація). Аіцитацією (лат. - аукціон, конкурент на торгах) відАавна називали відібрання кредитором майна боржника, який не виконав свого зобов'язання. ЗгіАно зі ст. 10 Закону України "Про порядок погашення зобов'язань платників податків перед бюджетами та Аержавними цільовими фондами", податковий орган у разі недостатності в платника податків Аодаткових Ажерел погашення суми податкового боргу має право продажу інших його активів. ОАнак зАійснити такий продаж податковий орган без рішення суду не зможе.

У разі невиконання власником своїх Аоговірних чи інших обов'язків на його майно може бути "звернено стягнення". Накладення стягнення на майно власника-боржника - це примусовий продаж цього майна заАля подальшого задоволення вимоги кредитора з виторгуваної грошової суми. Виконання такого рішення зАійснюється на підставі Аоговору між Аержавною виконавчою службою та спеціалізованою організацією шляхом продажу на прилюАних торгах (аукціонах) [7, с. 188].

Спеціальною підставою примусового характеру є також реквізиція.

Згінно зі ст. 353 ЦК України, у разі стихійного миха, аварії, епідемії, епізоотії та за інших наАзвичайних обставин з метою суспільної необхідності майно може бути примусово віАчужене 
у власника на підставі й у порядку, встановлених законом, за умови попереднього й повного віАшкодування його вартості (реквізиція). В умовах воєнного або наАзвичайного стану майно може бути примусово відчужене у власника з наступним повним відшкодуванням його вартості. Реквізоване майно переходить у власність держави або знищується. Оцінка, за якою попередньому власникові була відшкодована вартість реквізованого майна, може бути оскаржена в суд. У разі реквізиції майна його попередній власник може вимагати взамін надання йому іншого майна, якщо це можливо. Якщо після припинення наАзвичайної обставини реквізоване майно збереглося, особа, якій воно належало, має право вимагати його повернення, якщо це можливо. У разі повернення майна особі в неї поновлюється право власності на це майно, водночас вона зобов'язується повернути грошову суму або річ, яка була нею одержана у зв'язку з реквізицією з вирахуванням розумної плати за використання цього майна. Відповідні норми відтворено й у спеціальному законодавстві, зокрема в Законі України "Про правовий режим воєнного стану" [8]. Так, відповіАні органи мають право примусово віАчужувати майно, що перебуває в приватній або комунальній власності, вилучати майно державних піАприємств, Аержавних господарських об'єАнань Аля потреб Аержави в умовах правового режиму воєнного стану в установленому законом порядку та видавати про це віАповідні Аокументи встановленого зразка. Стаття 23 зазначеного Закону встановлює правила відшкодування збитків, завданих піА час уведення воєнного стану або повернення майна, що збереглося.

Реквізиція $€$ виключним способом припинення права власності, що зАійснюється в особливому порядку, спеціально встановленому Аля неї та за умови повного відшкодування вартості реквізованого майна Аля певної державної або іншої суспільно корисної мети. Майно може переходити у власність не фізичних чи юридичних осіб, а ^ише у власність держави або знищуватися. НаприклаА, в умовах воєнного стану в інтересах оборони держава може бути зацікавлена саме в знищенні певного майна - будівель, устаткування, яке не може бути евакуйованим.

Отже, Аля зАійснення реквізиції необхідними $\epsilon$, по-перше, Аоведеність загальної корисності тих заходів, заради здійснення яких проводиться реквізиція (зменшення негативних наслідків або недопущення настання негативних насліАків стихійного миха, реквізиція майна задля недо- пущення поширення епідемій, епізоотій тощо); по-Аруге, реквізиція вимагає безумовного віАшкодування вартості майна. У разі настання наАзвичайних обставин майно, що реквізується, може бути відчужене у власника, за загальним правилом, за умови попереднього та повного віАшкодування його вартості [9].

Оцінювання майна, що піАлягає примусовому відчуженню, зАійснюється юридичними та фізичними особами-піАприємцями, які є суб'єктами оціночної діяльності згідно із законодавством про оцінювання майна. У разі неможливості залучити Ао оцінювання майна суб'єктів оціночної Аіяльності - суб'єктів господарювання - таке оцінювання проводиться органами державної влади або органами місцевого самоврядування за погодженням із власником майна. У разі відмови або відсутності власника майна зазначені органи мають право проводити таке оцінювання самостійно. Оцінка майна, за якою попередньому власнику було відшкодовано вартість примусово відчуженого майна, може бути оскаржена до суду.

Законодавством України не передбачено примусового безоплатного вилучення майна у громадян і недержавних юридичних осіб у державну власність (крім конфіскації майна як санкції за правопорушення). У Конституції України прямо записано, що примусове віАчуження об'єктів права приватної власності може бути застосоване лише як виняток із мотивів суспільної необхідності, на підставі й у порядку, встановлених законом, і за умови попереднього та повного віАшкодування їх вартості, а в умовах воєнного чи наАзвичайного стану - з наступним відшкодуванням їх вартості (ст. 41). Отже, уже сьогодні в Україні встановлено конституційні гарантії неприпустимості безоплатного примусового вилучення об'єктів права приватної власності (тобто безопматної націоналізації).

Як зазначалося, існують випаАки, коли право власності може бути обмежене аж до його припинення, якщо цього потребують Аержавні або суспільні інтереси.

ОАним із таких випадків обмеження права власності в інтересахдержави та суспільства $€$ конфіскація, яка є безоплатним вилученням майна власника та Аопускається лише за рішенням суду як санкція за вчинення правопорушення у випаАках, установлених законом (ст. 354 ЦК України).

Конфіскація є водночас підставою припинення приватної власності й підставою виникнення державної власності. Як зазначав А. Мейєр, примусове відібрання майна у власника велінням 
Аержавної влаАи є таким способом припинення права власності, за якого з погляАу цивільного права переважне значення має не набуття права власності державою, а втрата його приватною особою; хоча Аержава набуває майно, це є насліАком утрати права приватною особою; норми цивільного права в цих випадках регулюють не набуття права власності, а його припинення [10, с. 95]. ОАнак необхіАно звернути увагу й на те, що як підстава виникнення права державної власності конфіскація має деякі особливості.

По-перше, конфіскація майна є виключним випадком, коли державою право власності на майно набувається безоплатно (що віАрізняє ії віА реквізиції, наприклаА).

По-Аруге, конфіскація майна є винятковим заходом, який може бути підставою виникнення права Аержавної власності мише у випадках, прямо визначених законом, коли конфіскація передбачається як санкція за вчинений злочин. Такі випадки передбачені Кримінальним кодексом (Аалі - KК) України, при цьому в ст. 59 КК України вказано, що "конфіскація майна встановлюється за тяжкі та особливо тяжкі корисливі злочини, а також за злочини проти основ національної безпеки України та громадської безпеки незалежно віА ступеня їх тяжкості і може бути призначена лише у випадках, спеціально передбачених в Особливій частині цього Кодексу". Отже, конфіскація як засіб покарання має бути спільномірною заподіяній правопорушенням шкоді. На необхідність Аотримання принципу спільномірності в разі позбавлення власника його прав звертається увага в практиці Європейського суду з прав ^юАини. Суд звертає увагу на те, що піА час розгляАу справ, пов'язаних зі втручанням у право власності, необхідно дотримуватися трьох норм, закріплених у ст. 1 Протоколу № 1 до Європейської конвенції з прав ^юдини, а саме: принципу безперешкодного користування майном, пов'язання випадків позбавлення майна з певними умовами, права держав-учасників здійснювати контроль за використанням власності відповідно до загальних інтересів. Суд зазначає, що Аля того, щоб втручання в право в^асності вважалося Аопустимим, повинна бути розумна відповідність між використовуваними засобами й тією метою, на яку спрямований буАь-який захіА, що позбавляє особу власності. ПіА час розгляАу справ необхіАно розгляАати, чи існує розумна віАповіАність між використовуваними засобами й метою, на яку спрямований будь-який захіА, що позбавляє особу власності.
Суду треба визначати, чи збережена необхінна справедлива рівновага [11].

Випалки конфіскації передбачені також Земельним кодексом України (ст. 148), Законом України "Про тваринний світ" (ст. 63), Законом України "Про захист тварин віА жорстокого повоАження" (ст. 12) тощо. ПоряАок вилучення й розпоряАження конфіскованим майном, що перехоАить у власність Аержави, врегульовано низкою спеціальних нормативних актів, зокрема Постановою Кабінету Міністрів України "Про ПоряАок обліку, зберігання, оцінки конфіскованого та іншого майна, що переходить у власність держави, і розпорядження ним", Постановою Кабінету Міністрів України «Про порядок обліку, зберігання, оцінки вилученого митницями АФС майна, щодо якого винесено рішення суду про конфіскацію, передачі цього майна органам державної виконавчої служби і розпорядження ним" тощо.

Як власник конфіскованого майна Аержава вправі розпорядитися ним у будь-який спосіб: продати з прилюдних торгів у визначеному порядку, передати в постійне чи тимчасове користування тощо. Варто також звернути увагу на той факт, що держава як власник не відповідає за зобов'язаннями попередніх власників конфіскованого майна, якщо ці зобов'язання виникли після прийняття державними органами заходів щодо охорони майна й без згоди зазначених органів. У зобов'язаннях колишнього власника Аержава відповідає мише в межах активу майна, що перейшло Ао неї.

ВисновкизАосліАження та перспективи пода^ьших розвіАок у цьому напрямі. СереА піАстав виникнення права власності найчастіше мають місце такі, що мають піА собою основу Аобровільності волевиявлення. ОАнак існують і ті, котрі мають примусовий характер Аля іншої сторони. I тут ідеться, як правило, про припинення права власності інших осіб і виникнення права державної власності. Тому варто враховувати положення норм глави 25 ЦК України «Припинення права власності». Так, відповіАно до ст. 346 ЦК України, право власності припиняється в разі: 1) відчуження власником свого майна; 2) відмови власника віА права власності; 3) припинення права власності на майно, яке, за законом, не може належати цій особі; 4) знищення майна; 5) викупу пам'яток історії та культури; 6) викупу земельної Аілянки у зв'язку із суспільною необхідністю; 7) викупу нерухомого майна у зв'язку з викупом $з$ метою суспільної необхінності земельної Аілянки, на якій воно розміщене; 8) звернення 
стягнення на майно за зобов'язаннями власника; 9) реквізиції; 10) конфіскації, 11) припинення юридичної особи чи смерті власника.

Частина з підстав виникнення права державної власності не має примусового характеру (відчуження власником свого майна; віАмова власника віА права власності тощо), але більшість із них має примусовий характер. Ао таких варто зарахувати викуп земельної Аілянки у зв'язку із суспільною необхідністю органом Аержавної влади; викуп пам'ятки історії та культури; набуття в державну власність майна в разі припинення права в^асності на майно, яке, за законом, не може належати особі; викуп нерухомого майна у зв'язку з викупом з метою суспільної необхіАності земельної Аілянки, на якій воно розміщене; звернення стягнення на майно за зобов'язаннями власника; реквізицію; конфіскацію. Крім цих піАстав, у законоАавчому порядку не врегульованою належною мірою залишається така підстава виникнення права державної власності примусового характеру, як реприватизація, котра потребує окремого наукового АосліАження з огляду на неоднозначність їі застосування і співвіднесення із суміжними правовими категоріями.

\section{NITEPATYPA:}

1. Ц Цивільне право України: підручник: у 3 кн. / Є.О. Харитонов, Р.О. Стефанчук, А.І. Дрішлюк та ін.; за ред. Є.О. Харитонова, А.І. Дрішлюка. Одеса: Юридична література, 2005. Кн. 1.

2. Х Харитонов С.О., Харитонова О.І. Цивільні правовідносини: монографія. 2-ге вид., перероб.і доп. Одеса: Фенікс, 2011.

3. Хміль О. Українська економіка: реприватизація неминуча? URL: https:/www.epravda.com.ua/publications/2009/06/1/194945/.

4. Реприватизація «Дніпроавіа»: Верховний Суд запустив позов ФДМУ по новому колу. URL: http://finbalance.com.ua/news/ Reprivatizatsiya-Dniproavia-Verkhovniy-Sud-zapustiv-pozov-Fondu-derzhmayna-po-novomu-kolu.

5. URL: http://protokol.com.ua/ru/obzor_praktiki_vs_ot_rostislava_kravtsa_opublikovannoy_s_18_po_30_iyunya_2018_goda_ (chast_vtoraya)/?utm_source=newsletter\&utm_medium=email.

6. URL: https://taxlink.ua/ua/tax_explained/analiz-deyakih-pitan-zastosuvannya-sudami-zakonodavstva-pro-pravo-vlasnosti-prirozglyadi-civilnih-sprav/\#hcq=e2stvpr.

7. Ромовська 3.В. Українське цивільне право. Право власності: підручник. Київ: Алерта: ЦУЛ, 2011. 246 с.

8. Про правовий режим воєнного стану: Закон України від 12.05.2015. Відомості Верховної Ради України (ВВР). 2015. № 28. Ст. 250.

9. URL: https://westudents.com.ua/glavy/72469-rekvzitsya.html.

10. Мейер Д.И. Русское гражданское право: в 2 ч. Москва: Статут, 1997. Ч. 2. 455 с.

11. Европейская конвенция о защите прав человека и основных свобод. Право на собственность / М. Карс-Фриск, А.Н. Жеребцов, В.В. Меркулов, А.Г. Эртель. Учебно-методическое пособие для судей. Москва: Российская академия правосудия, Совет Европы, 2002. URL: http://www.rrpoi.narod.ru/echr/commentary/st1pr1.htm.

\section{Кушнерук Амитро Володимирович}

\section{СПЕЦІАЯЬНІ ПІАСТАВИ ВИНИКНЕННЯ ПРАВА АЕРЖАВНОЇ ВААСНОСТІ ПРИМУСОВОГО ХАРАКТЕРУ}

Статтю присвячено визначенню нормативних актів, якими регулюються спеціальні піАстави виникнення права державної власності примусового характеру, їх аналізу з метою виявлення особливостей окремих видів піАстав набуття права державної власності й проблем, що виникають у цій сфері. Проаналізовано окремі види пілстав. Виявлено проблеми, що виникають піА час проведення реприватизації, реквізиції, конфіскації, ліцитації тощо. Проаналізовано сумісність загальної конфіскації та міжнародних норм щодо захисту права власності, реприватизації й захисту прав приватної власності. Виявлено проблеми в правовому регулюванні реприватизації.

Киючові слова: спеціальні підстави, реприватизація, реквізиція, конфіскація, ліцитація, примусове вилучення майна, право власності, Аержава, санкція.

\section{Кушнерук Амитрий Владимирович \\ СПЕЦИААЬНЫЕ ОСНОВАНИЯ ВОЗНИКНОВЕНИЯ ПРАВА ГОСУААРСТВЕННОЙ СОБСТВЕННОСТИ ПРИНУАИТЕЛЬНОГО ХАРАКТЕРА}

Статья посвящена определению нормативных актов, которыми регулируются специальные основания возникновения права государственной собственности принудительного характера, их анализу с целью выявления особенностей отАельных виАов оснований приобретения права государственной собственности и проблем, которые возникают в этой сфере. Проанализированы отдельные виды оснований. Выявлены проблемы, которые возникают при проведении реприватизации, реквизиции, конфискации, мицитации и Ар. Проанализирована совместимость общей конфискации и международных норм по защите права собственности, реприватизации и защиты прав частной собственности. Выявлены проблемы правового регулирования.

Киючевые слова: специальные основания, реприватизация, реквизиция, конфискация, мицитация, принудительное изъятие имущества, право собственности, государство, санкция. 


\section{Kushneruk Dmytro}

\section{SPECIAL BASES FOR THE STATE PROPERTY RIGHT OF COMPULSORY NATURE}

The article is devoted to the definition of legal acts which establish special grounds for the emergence of the state property right of compulsory nature, their analysis in order to identify the features of certain types of grounds for acquiring state ownership and problems that arise in this area. Certain types of grounds for the emergence of the state property are analyzed. The problems that arise during the reprivatization, requisition, confiscation, licitatio, etc. are identified.

The specific basis for the state property rights, which is not provided for in the legislation, but must be taken into account, is re-privatization. Since privatization is the basis for the termination of the state property rights, re-privatization is the return to state ownership of property that dropped out of such ownership illegally.

Classical re-privatization is a reverse process of privatization, a mechanism for returning property to the state, involves the re-sale of previously privatized property.

Sometimes re-privatization is identified with nationalization. However, unlike re-privatization, nationalization is the process of returning of non-state property objects, including previously privatized property, to state ownership for their further use considering the realization of national interests.

Another special reason for the emergence of state property rights is the forced sale of property (licitatio). Licitatio refers to the seizure by a creditor of the property of a debtor who has not fulfilled his obligation. In accordance with Art. 10 of the Law of Ukraine "On the Procedure for Repayment of Taxpayers' Obligations to Budgets and State Trust Funds", the tax authority, in case the taxpayer does not have enough additional sources to repay the amount of tax debt, has the right to sell its other assets. However, the tax authority will not be able to carry out such a sale without a court decision.

The compatibility of general confiscation and international standards for the protection of property rights, re-privatization and the protection of private property rights are also investigated in the article. Some problems of legal regulation are identified.

Key words: special grounds, re-privatization, requisition, confiscation, licitatio, compulsory seizure of property, property right, state, sanction. 